\title{
Politics, Political Parties, and the Party System in Nigeria: Whose Interest?
}

\section{Dhikru Adewale Yagboyaju, $\mathrm{PhD}^{1, \mathrm{a}}$ and Antonia Taiye Simbine, $\mathrm{PhD}^{2, \mathrm{~b}}$}

\author{
${ }^{1}$ Department of Political Science, University of Ibadan, Nigeria \\ ${ }^{2}$ Social and Governance Policy Research Department (SGPRD), NISER\& National Commissioner, \\ Independent National Electoral Commission (INEC), Nigeria \\ aaswaj2003@yahoo.com, btsombe98@yahoo.com
}

Keywords: party system, money politics, internal party democracy and intra-party feuding, public interest, Nigeria.

\begin{abstract}
Party system and the administration of political parties are critical factors in determining the direction of politics and democracy. Three political parties contested at the inception of Nigeria's Fourth Republic in 1999, but the number increased to more than 91 as at 2019. This paper raises fundamental questions as to whose interest - public or private interest of promoters and financiers these parties serve, and whether the increase in the number of political parties has significantly entrenched democratic values in the country? These questions are compelling because of several events in political party operations in the 20 years of the Fourth Republic. These include controversial and vexatious party primaries preceding every major election, often leading to protracted and distractive litigations and rampant political defections. Unregulated use of money has, in particular, restrained ample participation by women and youths, while violence is almost becoming a norm and permanent characteristic of the electoral and political system. The paper draws data from secondary documentary sources for its conceptual and theoretical contents. Primary data are generated from events analyses by the authors as observers at party conventions and other meetings for the selection of candidates for political offices as well as during general elections. This is complimented by content analyses of relevant documents including electoral laws, court and law reports, and reports by special committees such as the Electoral Reform Committee (ERC). A combination of the ecological approach and conspiratorial theory is deployed for the paper's analytic frame.
\end{abstract}

\section{Introduction}

Twenty years after the 1999 commencement of Nigeria's Fourth Republic, it is generally believed that although democracy seems to have come to stay, its processes and developmental outcomes are slow in coming. Thus, it is imperative to examine what critical components such as the party system and administration of political parties can do or have been doing in either facilitating or marring these expected outcomes. Democracies, whether in one-party or multi-party systems, rest heavily on the activities of political parties, and this accounts for this paper's emphasis on political party administration in Nigeria.

What is the character of the party system in Nigeria? Why, despite their existence for a considerably lengthy period, some since 1999, are political parties in Nigeria yet to be significantly managed like their peers in most parts of the developed world and many less developed countries? What are the foundational causes of protracted intra-party feuding and incessant political defections in Nigeria? Why is lack of internal democracy a common problem with many political parties in Nigeria? What are the effects of unregulated political finance on all of these? The objectives of this paper are to examine the place of party politics in Nigeria's multi-party democracy and whose interest, its political actors serve. Its research methodology is largely qualitative, and its instrument of analysis is a content analysis of published commentaries and materials on party politics and democracy in Nigeria. Together with this introduction, this paper is structured into four sections. The second revisits the conceptual/theoretical issues related to democracy and party politics in Nigeria, including a 
review of extant literature. The third focuses on the politics of party administration in Nigeria's Fourth Republic, with selected case studies. The paper offers its concluding remarks in the fourth section.

\section{Conceptual/Theoretical Issues and Review of Literature}

The centrality of administration, both in theory and practice, has been extensively discussed (Gulick 1937; Dimock 1937; Beard 1939; Adebayo 1981; Adamolekun 2002). Aspects of elementary knowledge of the discipline of administration tell us that administration has to do with getting things done, with the accomplishment of defined objectives (Yagboyaju 2016:1-33). There is a correlation between administration, electoral law and the number of political parties existing in a particular country. For example, in a one-party system, only one party is legally allowed to exist. As in China, the only party is the ruling party, which effectively functions as a permanent government (Yagboyaju 2019:113-138). The few other examples are socialist states as well as the various one-man dictatorships wrongly dubbed one-party states in Africa. In most two-party systems, there are more than two political parties. Thus, a two-party system may, conceptually, also be called a multi-party system. However, Nigeria experimented a two-party system with only two political parties, National Republican Convention (NRC) and Social Democratic Party (SDP), which were established by a military regime and which were in operation between 1990 and 1993 (see Yaqub 1992:41-66).

The number of parties is usually not specified in multi-party systems, even when power is often alternated between two parties. The United Kingdom (UK), United States of America (USA) and Nigeria, in its Fourth Republic, are examples. An exact number of parties could be legally and constitutionally recognized, especially where, as in Nigeria, they are required to be registered by an electoral body before they can operate. This implies that while the absolute number of parties is not apriori stated in the relevant laws, because "dynamism is the abiding law in the development of multipartyism" (Yaqub 2002:121), the exact number participating in the electoral process at any point could be known (Okoosi-Simbine 2004:85-102). Often in multi-party systems, no party is large enough to rule alone, therefore, leading to a system of coalition government.

Another unique feature of the multi-party system is the possibility of independent candidature, which often emerges not because independents have become political parties proper, but as a consequence of the determination of such forces "to provide to the electorate what probably the existing parties are presumed unable to provide" (Yaqub, p. 121). The USA is a system that is prominently recognized for independent candidature, while Nigeria has also in its Fourth Republic debated the possibility.Party system cannot and should not be simply reduced to a "number game" as it is not automatically linked to the existence of one or a multiplicity of parties. According to La Palombara and Weiner (1966:4), it is vital to establish the "relevance of parties" in relation to the formation of governments and, in particular, whether their size gives them the "prospect of winning or at least sharing governmental powers". Also important is the relationship within and between the "relevant" parties (see Agbaje 1999:191-209). For example, is the party system characterized by cooperation and consensus, or by conflict, acrimony and polarization?

As observed by Okoosi-Simbine (2004), Simbine and Oladeji (2010:807-840), and Yagboyaju (2019), cooperation and consensus accelerate growth and development, but conflict is also a critical component and, indeed, an inevitable part of the process. This being so, conflict management mechanisms are usually important elements of political parties and party systems. For Yagboyaju (2019, p.119), their effectiveness "determines the length and consequences of conflicts on the political system", and vitality of democratic rule. As analyzed in section four of this paper, the evident lack of compliance by most political parties to their own rules and regulations has severally caused hiccups and distortions in their operations in Nigeria's ongoing Fourth Republic.

Political parties perform certain broad functions most of which are universal in nature. While they are defined by a central function as platforms for contesting political office and wielding of governmental power, their impact on the political system and, especially, in realizing all that 
democracy promises is substantially broader and more complex. These general functions, according to Agbaje (1999:196-197), are:

- Representation;

- elite formation and recruitment;

- goal formulation;

- interest articulation and aggregation;

- socialization and mobilization; and

- organization of government.

Putting it differently, Ihonvbere (2009:13) summarized the functions of political parties as follows:

- Identifying and training leaders;

- developing policy platforms;

- presenting the best aspirants and candidates for office;

- regulating office holders;

- conducting research on party and political development;

- encouraging public discourses; and

- committing openly to the sustenance of democracy in every regards.

In carrying out these functions, political parties, particularly in Nigeria that is ethnically and culturally diverse, ideally, "reduce the salience and potency of ethnic chauvinism, bigotry and other manifestations of communal and cultural intolerance", which prevent ordinary citizens from meaningful engagement in public affairs (Yaqub 2002: p.122).A political party performs other functions, especially if it finds itself in opposition. These include educating, articulating and aggregating issues that the party feels the public is not well informed about or about which it has alternative options in addressing. A party stands a good chance of displacing and, thereby, taking power from the incumbent if the former performs the role of constructive criticism and articulation of alternative options competently. Such instances can be found in the USA, the UK, especially during the Brexit discussion of issues in 2018/2019 leading to the winning of more parliamentary seats by the Liberal Democratic Party and, to a considerable extent, in Nigeria's 2015 general elections when an incumbent president lost his reelection bid. However, effective opposition is still insignificant in Nigeria where power and relevance seeking politicians largely defect to the winning party (see Yagboyaju 2019; Simbine and Oladeji 2010).

Public interest is, ideally, the underlining motive of the functions of political parties as, indeed politics in the Aristotelian understanding is all about public service (see Aristotle, in Mclean and Mcmillan 2009:25-28). Built around ethics and morality, this notion of politics is negated by the Machiavellian idea of the end justifying the means (see Berlin 2013:1-20). The essence of public interest is emphasized in several aspects of African social values. For example, traditional ethical values and virtues espoused in the Omoluabi, Ujamaa and Ubuntu credos are done with a view to solving the bewildering amalgam of problems that confront the African continent (see Kehinde 2016:123-150). An omoluabi, whose replica is found within the context of the ujamaa and ubuntusocial values, is a person of integrity, dedicated to the service of a just community and selfactualization. The concept of omoluabi, according to Okome and Vaughan (cited in Kehinde, p. 124), encapsulates or distils the Yoruba "sense of the critical elements in the positive essences of a total/holistic self and being". As it is shown in section four of this paper, the blatant disregard for these values and the rapid replacement by the money culture largely accounts for the disconnect between political parties, political and bureaucratic elites, and the generality of ordinary citizens whose interests the former supposedly represent (see Yagboyaju 2007:34-57). 


\section{Issues in Party Administration}

Democratic governance is about functional institutions capable of transforming government policies into infrastructural development and sustainable economic growth required for the wellbeing and self-actualization of the generality of the citizens. Links between such institutions as the legislature and the political components of the executive arm of government, and political parties that mostly present holders of legislative and elective executive positions cannot be overemphasized. Strong political parties or, in general, functional institutions, however, hardly emerge without directional leadership. Authors of the 2012 bestseller, Why Nations Fail, Daron Acemoglu and James Robinson (cited in Olaopa 2019:16), have espoused the resurgence of the new institutionalism as a theory of looking at human society and at the role of strong personalities.

The origin of parties, according to Leeds (1981:127), has been attributed primarily to the fact that "men differ in character and temperament from their fellows". There will consequently be "differences of opinion, unanimity being difficult to achieve". Taken further, this theory stresses the "pugnacious instinct of man, his tendency towards combativeness and choosing of sides in an attempt to give organized expression to the competitive instinct". Modern parties emerged in view of the growth of democracy and extension of the franchise which gave the mass of the people opportunity to play active part in political activities. These include more formal organization, full-time official activities, mass membership and systematic political programmes accountable to the membership (Mclean and Mcmillan, p.393). For example, the Reform Bills of 1832 and 1867 in Britain resulted in formal political machinery being established by both the Conservative and Liberal parties. Left wing socialist parties, or parties of the underprivileged, emerged only with the further liberalization of franchise. Germany's Social Democratic Party emerged after the repeal of the anti-socialist laws in 1890.

Analysis of party structure and organization has been undertaken by Robert Michels (1911) and Maurice Duverger (1978), in their well cited works on political parties. Various forms ranging from the caucus, branch, cell, machine, to bossism have been identified. Of importance are the ideas behind the "iron law of oligarchy" espoused by Michels (see Leeds 1981, pp. 139-140), which have been found relevant in discourses on organizations, whether democratic or autocratic. In essence, it says only the few active members of political parties, as in human organizations in general, attend meetings, draft party policy, hold office and choose candidates and leaders. This, in part, is also the fundamental idea behind the elite perspective in politics and democracy.

Activities of political parties commenced in Nigeria with the formation of the Herbert Macaulay - led Nigeria National Democracy Party (NNDP) and its participation in the Lagos council elections of 1922. Pioneering efforts in documenting the activities of this and other political parties in the country include Hodgkin 1961; Post 1963; Sklar 1966 and 1983; Dudley 1968; and Coleman 1971. Several other efforts have subsequently been made (see Joseph 1987; Diamond 1988; Yaqub 2002). The critical issues being addressed in the activities of Nigerian political parties are funding, intra-party feuding and defections.

Without necessarily romanticizing the past, consensus of opinions about Nigeria's First and Second Republics is that of a better performance by the political parties than in the Third and Fourth (ongoing). These opinions by Okoosi-Simbine 2004, Simbine and Oladeji 2010, Onuoha 2002, Iwu 2008, and Yagboyaju 2019 among others emphasized effective adherence and compliance with party regulations on funding, selection of candidates and general conduct with particular reference to discipline and hierarchy. Also included is the higher level of conformity and compliance by political parties of that time with general regulations in the country's electoral framework. On a comparative note, Olurode (2017:69pp) and Adetula (2008:xxvii-xxxiv) emphasized the increasing phenomenon of "money culture" and the monetization of politics in the latter periods. Detailed analysis of this is done in section four of this paper. 
However, it is important to note the high levels of political violence in Nigeria's First and Second Republics. For example, post-election violence partly accounted for the fall of the two dispensations in 1966 and 1983 respectively. While controversial election results have been largely associated with the acts of political violence, factors of political defections and the reactions they generated are also of importance. For example, operation weti e (petrol-bombing of houses and other physical structures) and other forms of violence, which turned the then Western region into the "Wild, Wild West", were obviously targeted more at defectors presumed to have collaborated to rig the 1965 elections in Western Nigeria (see Kirk-Greene and Rimmer1981; Roberts 2010:687-730; Olurode 2017). The pattern, going by the accounts on the experiences of defectors in old Oyo and Ondo States, in particular, was not different in the aftermath of the controversial results of the 1983 gubernatorial elections (see Olatunbosun 2018:15pp).

The effects of political violence and the relationship with defections are analyzed in details in a subsequent section of this paper. Explanations are also provided for the increase in the cases of defections, especially in the ongoing Fourth Republic and the possible effects on democratic growth in Nigeria. This is examined along with the issue of women and youth political participation. Of course, public interest is jeopardized when the overwhelming population of women and youths does not come into serious consideration in political calculations (Okoosi-Simbine 2007:200-215).

It is appropriate to provide hints on the ecological approach and conspiratorial theory utilized for the analytic frame of this paper. The origins of the ecological approach in political, administrative and management sciences can be traced to the initial efforts of Gau (1947:1-19) and Riggs (1962:915). The central concept is the ecology or environment within which a system or organization operates. In essence, the organization; and the political party in this instance, is a product of the peculiar social, cultural, historical, economic, geographical, and technological milieu within which it operates. In the etymological form of the phenomenon of conspiracy, from which the conspiratorial theory originated, it is denoted as a secret plan or agreement to do something wrong. It can even be part of a decision to remain silent or to say nothing about something that is wrong. Uscinski, Klofstadand Atkinson (2016:57-71) provide summarized views on earlier efforts on the concepts of conspiracy and conspiratorial theory in political science.

In its theoretical groundings, conspiratorial approach in the formal study of politics also shares certain similarities with ideas on elitism espoused by Vilfredo Pareto (1848-1923), Gaetano Mosca (1858-1941) and Roberts Michel (1876-1936) among others. The conspiratorial element of politics can be situated in the Machiavellian notion of the end justifies the means than the Aristotelian philosophy of service through politics. In the former, the outcome is more important than the process, whilein the latter both the process and outcome are of importance.

\section{Selected Cases in the Fourth Republic}

The critical issues being analyzed in this section are: (i) political finance and party ownership; (ii) primary elections and imposition of candidates; (iii) litigations; (iv) defections and (v) violence. Observable exclusion of females and youths from effective political participation is analyzed as crosscutting viz, part and parcel of the selected cases at different stages in the paper. While most examples and illustrations are drawn from the ongoing Fourth Republic in Nigeria, other relevant instances are drawn from earlier dispensations.

The literatureon political finance in Nigeria is rich (see Onuoha 2002; Okoosi-Simbine2004; Akande and Simbine 2008; Adetula 2008; Yagboyaju 2009; Simbine and Oladeji 2010; Eme and Anyadike 2014:22-34; Sule, Azizuddin and Mat 2017:15-31). The subject has also attracted scholarly attention in other places around the world. For example, the Organization of American States - OAS (2011), Londono and Zovatto (2014:129-171) and Kapur and Vaishnav (2018) among others have also contributed to the debate on political finance. For Walecki (2008:1-7), who focused on a comparative analysis of levels of compliance with political finance regulations in Nigeria and many countries around the world, such regulations are often honoured in the breach in Nigeria. Political 
parties and their candidates often exceed spending limits stipulated by the country's electoral laws. Yet, in the 20 years of the Fourth Republic, nobody is known to have been punished for such violations. This is largely because there are no sanctions, they are inadequate, or not easy to verify and execute.

Sections 88-93 of the 2010 Electoral Act, which is in operation in Nigeria, have provisions for the following issues in political finance: offences in relation to finances of a political party; period to be covered by annual financial statements of political parties; power to limit financial contribution to a political party; limitation on election expenses; disclosure by political parties; and penalties for violations or non-compliance. Furthermore, the Independent National Electoral Commission (INEC) summarized items concerning political finance in its 2017 publication, Political Finance Manual, as part of its monitoring role as Nigeria's main election management body. These items are expenses by parties, their candidates and the rules on disclosure; books of accounts and regulations guiding them; rules on anonymous contributions or donations and; regulations on audited returns (INEC 2017:2527). The Commission relies on Sections 100 (1) and 153 of the Electoral Act to carry out this duty as well as others that are associated with public enlightenment and voter education. INEC draws strength from relevant sections of the 1999 Constitution (as amended) and the Electoral Act to publish the following spending limits and penalties for violations, in Tables 1 and 2 below.

Table 1: Spending limits for candidates

\begin{tabular}{|l|l|}
\hline \multicolumn{1}{|c|}{ Position } & Spending Limit \\
\hline Presidential candidate & N1 billion (approx. \$3.18million) \\
\hline Governorship candidate & N200 million (approx. \$636,700) \\
\hline Senatorial candidate & N40 million (approx. \$127,300) \\
\hline Member, House of Representatives (MHR) & N20 million (approx. \$63,700) \\
\hline Member, State Assembly & N10 million (approx. \$31,800) \\
\hline LG chairmanship candidate & N10 million (approx. \$31,800) \\
\hline LG councillorship candidate & N1 million (approx. \$3,180) \\
\hline
\end{tabular}

Source: 2010 Electoral Act (as amended); US dollar conversion based on the prevailing N360: \$1 rate, between 2016 and 2019.

Table 2: Sanctions for spending above limits

\begin{tabular}{|l|l|}
\hline \multicolumn{1}{|c|}{ Position } & \multicolumn{1}{|c|}{ Sanction } \\
\hline Presidential candidate & $\begin{array}{l}\text { Fine of } \\
\text { imprisonment or both) }\end{array}$ \\
\hline Governorship candidate & $\begin{array}{l}\text { Fine of } \\
\text { imprisonment or both) }\end{array}$ \\
\hline Senatorial candidate & $\begin{array}{l}\text { Fine of } \\
\text { imprisonment or both) }\end{array}$ \\
\hline Member, House of Representatives (MHR) & $\begin{array}{l}\text { Fine of } \$ 500,000 \text { (approx. \$1,373 or } 5 \text { months } \\
\text { imprisonment or both) }\end{array}$ \\
\hline Member, State Assembly & $\begin{array}{l}\text { Fine of } \\
\text { imprisonment or both) }\end{array}$ \\
\hline LG chairmanship candidate & $\begin{array}{l}\text { Fine of } \\
\text { imprisonment or both) }\end{array}$ \\
\hline LG councillorship & $\begin{array}{l}\text { Fine of } \$ 100,000 \text { (approx. \$274 or } 1 \text { month } \\
\text { imprisonment or both) }\end{array}$ \\
\hline
\end{tabular}

Source: 2010 Electoral Act (as amended); US dollar conversion based on the prevailing \$360: \$1 rate, between 2016 and 2019. 
The adequacy of the regulations on spending limits and sanctions for violations in Tables 1 and 2 above can be questioned on some grounds. For example, INEC can only report suspected violators and situations to security agencies but is not empowered to prosecute electoral offenders whether in terms of non-compliance with regulations on spending limits, disruption of electoral process or any other related offence. Therefore, the absence of prosecution and, if necessary, punishment of any known culprit in relation to political finance violations may not be a result of the Commission's lack of performance. It is more appropriate to trace this to the factor of inadequate investigation and prosecution by security agencies and, in particular, the Police. This is part of the noticeable features of most newly established democracies. As Walecki (2008: 9) has put it, the systems in most of these newly established democracies make a "slow start in promoting the specialization of the police, judiciary and other enforcement bodies in the fight against illegal funding of political parties.

Also, the penalties, in terms of fines or jail terms for offenders, appear lenient but it must be noted that efficiency of regulations and laws lies more in their functionality than their stiffness. This aside, there are elements of impracticability and inconsistency in the spending limits. For example, the limits do not reflect economic realities in the country, including factors of inflation and currency exchange rates. The naira to US dollar exchange rate was about $\$ 200$ to US $\$ 1$ as at 2010 when the regulations on spending limits in Table 1 became operational. The exchange rate became $\$ 360$ to US \$1 late in 2015 and has been so four years after. Exchange rate volatility, high and variable inflation and other indicators of growth are key elements in Nigeria's economy and, therefore, they play active roles in determining the practicability and consistency of campaign financial limits.

Other things being equal, the approved amount for the different categories of office seekers, about a decade ago was obviously inadequate even as at that time. For example, travels and tours for presidential and governorship candidates whose campaigns often require physical appearances in the nooks and crannies of their constituencies, would gulp far beyond their entire approved spending limits. In view of the difficulties in accessing riverine areas and other communities in the creeks as well as the deplorable conditions of physical infrastructure, particularly roads, many candidates and even party top shots opted for the more accessible but expensive (private) air travels during the 2019 general elections. Prominent among them are President Muhammadu Buhari and Atiku Abubakar, presidential candidates of the All Progressives Congress (APC) and People's Democratic Party (PDP) respectively. Others included national executive council members of political parties as well as stalwarts and financiers in some instances. This and similar incidental expenses are obviously huge but not necessarily put into consideration by the framers of the regulations guiding political finance in today's Nigeria.

Of all the questions that have been raised on the adequacy of these regulations and sanctions, the most troubling has to do with ease of verification and reporting of spending beyond limits as well as efficiently executing the laws. For example, USAID and UKAID reported in their 2015 study, Still Above the Ceiling, that APC and PDP exceeded the maximum of 1 billion for a presidential candidate, on media advertisement alone. According to them, PDP spent $\$ 8,749,685,296$ while APC spent $¥ 2$, 915,846,737 (cited in Sule, Azizuddin and Mat 2017:24), representing 800\% and 200\% excess for the two parties, respectively. It is probably more because the expenses were estimated owing to the difficulties associated with verification. It is even more worrisome that despite the figures, no further investigation or prosecution is known to have been carried out. These are serious concerns begging for attention in the regulations guiding political finance in the Fourth Republic. Preliminary reports by INEC in respect of tracking political finance in the 2019 general elections are also largely based on estimations.

The role of money in politics cannot be deemphasized. This consists of two sides - the one with enabling effects for democratic growth, and the other with destabilizing effects and of massive corruption of the electoral and democratic processes. The views of Olurode (2012:4) are relevant on this. He asserted: 
Campaign expenses include logistic issues -budgeting for mobilization and movement; campaign venue and decoration; engaging entertainers and cultural workers; publicity matters - radio and TV advertisements, posters and pasting; feeding arrangements including drinks and sometimes hard drugs for political thugs; spiritual protection including juju (charms), engaging marabouts and prayer warriors; renting a crowd; security expenses - both formal and informal security coverage.

Direct interactions with party organizers and mobilizers revealed that rain "holders" and "makers" are also paid to forestall disruption of campaigns and other open-air meetings, on one hand and, on the other, to disorganize the meetings of opponents ${ }^{1}$. There are also expenses that are improbable without the characteristic transactional relationships in politics in Nigeria. These include settlement of hospital bills of supporters, especially during active service; financing of naming, marriage and funeral ceremonies of supporters or their dependents; and settlement of school fees among others. These are apart from the more recognized expenses such as rental, purchase or building of party secretariats, providing for the day-to-day running, equipment and staffing as well as payment for party agents, especially during elections.

Political finance and its effects on ownership of political parties are sources of concern in Nigeria's politics and political life. The fear of possible hijack of political parties and, by extension, the government by an individual or group of individuals is real, and that has been part of the debate on funding of political parties for some time. Funding by ordinary members, through the payment of registration fees, membership dues and levies was popular in Nigeria's First Republic (1960-1966) and, to a lesser extent, in the Second Republic (1979-1983). Political parties at that time also generated revenue through involvement in commercial activities such as newspaper printing, banking and sale of party constitutions and other printed materials among others to members. The establishment of two parties of "equal founders and equal joiners "and their funding by the government, as part of the political experiment between 1989 and 1993, changed all of these (see Onuoha 2002; Iwu 2008; and Yagboyaju 2019). The then two parties, National Republican Convention (NRC) and Social Democratic Party (SDP) collapsed with the failure of the Third Republic in 1993.

The period of military rule in 1985-1993 and, thereafter, from 1993-1999, coincided with the emergence of a new class of stupendously wealthy Nigerians. This group, with an overwhelming population of individuals in their middle ages and from backgrounds in commercial activities mostly related to foreign exchange trading, banking and finance, oil and gas servicing, and general importations, had a common identity of being connected to the military (Amao, 2016)d. Mostly males, these financial whizzkids of two decades ago played different prominent roles in the registration and funding of some of the five political parties in the short-lived transition programme of 1996-1998. They were actively on ground at the inception of the Fourth Republic and, as such, they have played active roles in its direction in the 20years of its existence (see Yagboyaju 2019:113138). This has implications for active political participation by females and ordinary youths in general. For example, the same names and personalities have been recycled over the years making it difficult for new entrants, especially females and young persons to take a chance and effectively participate in politics and governance (see Oni and Simbine2002:239-261). Olurode (2013:31pp) has analyzed how differential treatment of men and women stifle women's economic, political and social inclusion but, in particular, how this 'threatened and fettered their citizenship rights during Nigeria's 2011 general elections" (p. 6).

\footnotetext{
${ }^{1}$ Instances of cloudy weathers in which rain did not fall until after campaigns, witnessed by the authors in 2018 and 2019 , were possibly accidental and providential.
} 
Primary elections and the associated issue of imposition of candidates have also attracted concern in the Fourth Republic. For example, starting from the first primaries of the PDP and Alliance for Democracy (AD), in 1999, in which Olusegun Obasanjo and Olu Falae emerged as presidential candidates for their respective parties, big spenders have been prominent (see Okoosi-Simbine 2005; Akande and Simbine 2008). According to Oshun (2005:52pp), the AD primary election brought Afenifere, the core socio-cultural and political group of the Yoruba nation, to its knees and it is yet to recover from the imbroglio. Falae won AD's controversial primary election in Ibadan, Oyo State, to defeat Bola Ige, a veteran in the Awolowo political family and who, in view of his many years in active partisan politics, was expected to emerge as the candidate of AD.

Party flags may be conceded to top favourites of godfathers who possibly did not participate in party primaries on the rare occasions when these are effectively conducted. For example, in the 2007 elections, PDP's governorship candidates' lists were changed in many states. Rivers, Kebbi and Sokoto are selected for illustration. In Rivers State, the party flag was handed over to Celestine Omeiha instead of Rotimi Amaechi who won the primary election. Omeiha contested and won on PDP's platform but his votes were transferred to Amaechi by the Supreme Court, the latter being the authentic PDP candidate. In Kebbi and Sokoto States, the governorship candidates initially presented by the All Nigeria People's Party (ANPP) to INEC were later adopted by the PDP for the same election. The candidates in question "won" the elections on the platform of the PDP, but the victory was overturned at the appellate court on the ground that candidates were not members of the PDP at the time their names were forwarded to INEC (see Ugochukwu 2009:204pp).

Elsewhere, in Adamawa and Kogi States, the courts also dealt with the rights of candidates to participate in the 2007 elections. In both states, INEC unlawfully excluded candidates properly nominated by their parties from taking part. For Ibrahim Bapetel of Action Congress (AC)in Adamawa State, the Resident Electoral Commission (REC), who ordered the removal about 24hours before the election, offered no cogent reason other than an oversight. In Kogi State where the name of Abubakar Audu, a former governor and candidate of ANPP was removed, INEC based the removal on an unproven allegation of corruption. Fresh elections were ordered in the two states. These examples represent some of the sensational cases of arbitrariness in the 2007 exercise.

Other serious issues of intra-party feuding include the unofficial designation of the president and governors as leaders of political parties at the national and state levels. PDP and the APC are the only parties that have controlled the presidency since 1999 - PDP: 1999 - 2015 and APC 2015 till date and, therefore, they are selected as examples. For PDP, especially under the Obasanjo presidency, this arrangement accounted for the uneasy relationships between the then president, the party executive, and the leadership of the National Assembly. Many of the cases of sudden removal of the party's national officers, replacement of nominated candidates for elective public offices based on the "advisory list of the Economic and Financial Crimes Commission (EFCC), in 2007, and controversial suspension of members have been traced to President Obasanjo (see Adejumo 2010:89125; Yagboyaju 2019, Amao 2020). Obasanjo's successors, Umar Yar'Adua (2007-2010) and Goodluck Jonathan (2010-2015) respectively, inherited the crises in the party and managed them differently. The protracted sickness of Yar'Adua, which effectively nullified any aspiration for a second term in office, was sufficient reason for the relatively low-level effects of these crises under his presidency. Jonathan was, in particular, confronted by the intense struggles within the party to return political power to the North by 2015 and the politics associated with the leadership of the Nigerian Governors Forum (NGF) (see Adetula2014:313-335; Lalude2014:216-235).

Those who challenge arbitrariness in party administration may be expelled or even killed if they could not be silenced. For example, PDP expelled Amaechi of Rivers State while his case in connection with the 2007 governorship election was ongoing in the court. The Supreme Court deplored the party for "bringing the administration of justice to disrepute" (Ugochukwu 2009, p. 68). The expulsion of Atiku Abubakar, then vice president, and his loyalists who disagreed with President Obasanjo in the build up to the 2007 general elections is another case in reference. It attracted intense media war and fierce battles of verbal exchanges between "new" and "old" PDP, with serious 
distractive effects on the quality of governance. Imposition of candidates and litigations are real issues in political party reform in Nigeria and they had, as at June 2019, accounted for court-ordered withdrawal of more than 80 certificates of return earlier issued by INEC in the 2019 general elections alone $^{2}$. Among these, the case of Zamfara State stands out. The governorship candidate of the APC, his deputy, all state assembly and national assembly members hitherto elected on the platform of the party in the 2019 exercise were removed having emerged from an unrecognized party primary (www.punchng,com) and the election handed over to the PDP on a platter of gold.

Defection is an important phenomenon in party politics and is based on democratic principles of freedom of association. It is a regular occurrence even in mature democracies such as the United Kingdom (UK), United States of America (USA), Germany and Canada among others. It is also not a recent development in Nigeria as many instances have been cited in the country's past republics (see Yagboyaju 2019). However, attention is being drawn to the frequency of defections and their distractive tendencies that are not in the interest of the generality of ordinary Nigerians in the ongoing dispensation. Political heavyweights including Muhammadu Buhari (left ANPP to form the Congress for Progressive Change (CPC), the platform on which he contested the 2011 presidential election), Atiku Abubakar, governors, ex-governors and many senior parliamentarians as well as others that are relatively less prominent have defected at different points in time. Many are serial defectors, labelled by Olatunbosun (2018:8) with the description, "the Atiku phenomenon", while according to OkoosiSimbine (2005:17-33), they exemplify "political vagrancy". Atiku Abubakar's role ${ }^{3}$ in fighting imposition of candidates, especially in the PDP ahead of the 2007 general elections, and his popularization of the concept of "internal democracy" as part of the political lexicon in Nigeria's Fourth Republic has been well documented (see Abubakar 2013:17pp; Yagboyaju2019).

Okoosi-Simbine (2005) and Olatunbosun (2018) among others have sought explanations for the rampant political defections since 1999, when the Fourth Republic commenced. In these efforts, defections were interrogated as to explain whether they are for altruistic purposes from which the public stands to gain or mainly to serve the narrow interests of the defectors. There are serious issues around political defections in today's Nigeria, including lack of effective internal conflict management mechanisms in many of the political parties, ideological vacuity, and excessive and unregulated use of money in politics. However, a critical point to note in the pattern of political defections is the inordinate ambition and, sometimes, desperation on the part of the average politician. This partly accounts for many defectors' insistence on automatic tickets in their new parties. With a mindset of winning at all cost, it is not surprising that the average Nigerian politician has an attitude of "do-or-die", life and death towards politics.

Several ills and consequences that are associated with political and electoral violence, including instability, economic hardship and importantly, loss of properties, livelihood and lives, are well documented in the literature (see First 1970; Anifowose 1982; Joseph 1987; Diamond 1988; Olurode and Jega 2011). According to the United Nations Economic Commission (UNECA 2013: 1 ), the very essence of elections is undermined because of the "difficulties encountered in making a peaceful leadership a reality". This assertion was tested ${ }^{5}$ in a simple survey by these authors, which revealed that six out of ten respondents or $60 \%$ chose not to vote in 2015 and 2019 for fear of election related violence. The low voter turnout in these two exercises is, therefore, partly traceable to the

\footnotetext{
${ }^{2}$ Address of Oyo State REC as representative of INEC chairman at the International Conference on the 2019 General Elections in Nigeria, organized by the Programme on Ethnic and Federal Studies (PEFS), Ibadan, 2526 June 2019.

${ }^{3}$ Former Vice President Atiku Abubakar delivered a Distinguished Personality Lecture at the University of Ibadan, on 13 March 2013.

${ }^{4}$ The then President Obasanjo said at a campaign rally in Abeokuta, Ogun State, that the April 2007 polls were a do-ordie affair for the PDP. This was widely reported in the media.

${ }^{5}$ The authors conducted a survey among the university students in Ibadan, Lagos and Abuja shortly before and after the 2015 and 2019 Nigerian general elections.
} 
factor of violence, indirectly obstructing the realization of the goal of the rule of the people regarded as the basis of democracy and effective governance. Yet, disturbing as it is, a consensus of opinions is that violence before, during and immediately after elections in Nigeria is almost becoming a norm irrespective of whether it is a general election or election within a political party.

The list of assassinations that have been linked to political and election related violence since the return of civil rule in Nigeria is rather lengthy. These include the assassination of: Chief Bola Ige, then Nigeria's Minister of Justice and Attorney General, in 2001; Mr. Abayomi Olagbaju, member of Osun State House of Assemly, in 2001; Dr. Harry Marshal, chieftain of the ANPP, in 2003; Chief Aminaosari Dikibo of the PDP, in 2003; Chief Funso Williams, governorship aspirant and leading member of the PDP in Lagos State, in 2007; Mr. Ayo Daramola, governorship aspirant of the PDP in Ekiti State, in 2006; Mr. Monday Udoh of the ANPP, in 2003; and Mr. Andrew Agom of the PDP, in 2005 among others (Olaniyan and Amao, 2015; Omilusi and Amao, 2019).

Despite initial arrests in connection to these cases, none of which is less than ten years, there has been no conviction or commensurate punishment known to the public. There have also been numerous cases of low-profile casualties during elections, rallies and other political activities. According to Egwu, Leonard and Matlosa (2009: 108-144), the unofficial death toll in Nigeria's 2007 general elections was “200, and about 800, resulting from post-election violence in the country's 2011 general elections" (cited in UNECA 2013:146). The fate of the victims in the latter cases is worse as there is hardly any evidence that proper investigations let alone prosecution were carried out.

During the country's most recent general elections in 2019, various forms of election-related violence, sometimes notably occurring without any form of restraint or reprimand from security agencies on election duties, were observed and recorded. Reports by the Youth Initiative for Advocacy, Growth and Advancement (YIAGA) Africa, and Centre for Democracy and Development (CDD $)^{6}$ among others have been useful. Reports on violence and the 2019 general elections included:

(a) Intimidation and harassment of INEC permanent and ad hoc staff, voters and observers by politicians, their supporters, and political thugs at polling units and collation centres.

(b) Abduction of INEC permanent and ad hoc staff in Akwa Ibom, Bauchi, Imo, Katsina, Kogi and Rivers States.

(c) Seizure and burning of election materials, including stuffing of ballot boxes.

(d) Disruption of results collation processes at collation centres, through interference with the collation process, deliberate targeting of election and collation officials while on their way to collation centres as in Akwa Ibom, Delta, Rivers and Zamfara States.

(e) Destruction or arson of property, including INEC offices in Ebonyi, Anambra, and Plateau States.

(f) Excessive militarization of the election process, including the voting process, such as "incidence of military personnel chasing away observers and some party agents", on election day especially in Akwa Ibom, Imo and Rivers states.

(g) The circulation of fake news, misinformation, and hate speech as a form of psychological violence, to instigate and precipitate physical violence and social disturbance during the elections (cited in Jinadu 2019:15).

There are serious implications in these reports. Prominent among them are the psychological assault on abducted permanent and ad hoc electoral officials as well as physical injuries inflicted on some and casualties recorded in others. However, the implied complicity on the part of security agencies calls for greater concern. Despite being part of election duties, instances have been cited of security agencies' partisan involvement, lack of restraint or non-reprimand of violators. Instances can also be drawn from the economic sector to buttress the analyses of the consequences of pre-and postelection violence. For example, selected reports from the Nigerian Stock Exchange (NSE) market and 
National Bureau of Statistics (NBS) provide information on certain sensitive sectors of the national economy shortly before and after some major elections in Nigeria. Market capitalization before the 2015 elections was " $\$ 13.22$ trillion but dropped to $\$ 11.47$ trillion during the elections". Gain and loss on investment were " $8.8 \%$ and $8.5 \%$ respectively" before and shortly after the exercise (NSE 2015).

In December 2014, exchange rate was " $\$ 185.27$ for US $\$ 1$ ", plummeting to " $\$ 198.85$ for US \$1" by April 2015 and dropping further thereafter. Oil export, the mainstay of the national economy, dropped from over "two million barrels per day (bpd) to just a little over one million bpd", all because of uncertainties traceable to the electoral exercise (NBS 2015). This was further compounded by the sharp drop in the international price of crude oil, accounting for the country's economic recession of 2016-2018. The cost of politics in Nigeria (see Olorunmola 2017:1-21); but for the purpose of this paper, the cost of elections, has generated debates as to whether it is reasonable in view of the challenges that have confronted the country since the economic recession of 20162018.

Of particular concern, in line with the focus on the interests of political parties in Nigeria's ongoing Fourth Republic, is the position of the political class on this issue. It must be noted that the administrative cost of elections which significantly rose since 2015 became higher in 2019. For example, the projected cost of the 2019 general elections in 2018 was " $189,207,544,893.13$ up from the $\$ 122,950,818,933.15$ cost of the 2015 general elections" (Kuna cited in Jinadu 2019:18). This amounted to a projected increase of $\$ 66,346,725,959.98$ or $62.3 \%$ over the 2015 cost. Table 3 below provides information:

Table 3: Summary Cost of 2015 and projected cost of 2019 general elections in Nigeria

\begin{tabular}{|l|l|c|c|}
\hline S/N & \multicolumn{1}{|c|}{$\begin{array}{c}\text { DESCRIPTION OF } \\
\text { EXPENDITURE }\end{array}$} & $\mathbf{2 0 1 5}$ & $\mathbf{2 0 1 9}$ \\
\hline 1 & Election Operational Cost & $100,336,102,305.50$ & $134,427,868,157.50$ \\
\hline 2 & Election Technological Cost & $10,530,659,786.00$ & $27,503970,680.00$ \\
\hline 3 & Election Administrative Cost & $9,007,451,501.82$ & $22,660,887,887.50$ \\
\hline & TOTAL & $\mathbf{1 1 9 , 8 6 4 . 2 1 3 , 5 9 3 . 3 2}$ & $\mathbf{1 8 4 , 5 9 2 , 7 2 6 , 7 2 5 . 0 0}$ \\
\hline 4 & Miscellaneous Expenses & $2,996,605,339.83$ & $4,614,818,168.13$ \\
\hline & GRAND TOTAL & $\mathbf{1 2 2 , 8 6 0 , 8 1 8 , 9 3 3 . 1 5}$ & $\mathbf{1 8 9 , 2 0 7 , 5 4 4 , 8 9 3 . 1 3}$ \\
\hline
\end{tabular}

Source: L. Adele Jinadu, Elections, Democracy, and the State in Africa: The 2019 Nigeria Elections in Perspective. Keynote Address at the International Conference on 2019 Elections in Nigeria, 25-26 June.

As shown in table 3, the major increase came from election technological and administrative cost, which is connected to the deployment of high technology such as biometric data registration and smart card readers all of which were introduced in 2015. Investing in high technology and strategic administrative planning by INEC led to some consequential developments, especially in its application during the preparatory stages in the 2019 general elections. First, more than the controversy over the sequence of the elections in which the major opposition party, the PDP, was prominent, the logjam in the National Assembly over the passage of the passage of the Electoral Amendment Bill of 2018 was due to "disagreement over the mandatory use of the smart card readers and the electronic transmission of election results during the exercise" (Jinadu 2019, p.19). Secondly, in the light of the modest sanitizing effectiveness of high technology during the 2015 general elections, those from within the political class determined to undermine the integrity of the 2019 electoral exercise resorted to more blatant violent measures. 
These, according to Jinadu (p.19), included acts of arson by "burning INEC offices, polling units, ballot papers, and ballot boxes stuffed with cast ballot papers". They also willfully disrupted election-day processes, as in the cases of parts of Lagos, Rivers, Akwa Ibom, Sokoto and Kano States, including preventing the use of smart card readers and the abduction of polling officials to cause mayhem, contrive inconclusive elections and generally to dent the integrity of the elections. The integrity cost of high technology may initially appear prohibitive but, in the middle-to-long term, it is potentially a worthwhile cost-saving and confidence-building investment towards growing democracy in Nigeria (see Olurode 2017a: 799-811; Kumuyi and Adeyinka 2002: 370-403). It is of great benefits in addressing the election conundrum and governance crises in Nigeria and, therefore, in the interest of the greatest number of the citizens and residents.

The analytic frame deployed in this paper is built on a combination of the ecological approach and conspiratorial theory. It analyzes the effects of culture, history, economy, technology and education, as factors in Nigeria's socio-economic milieu, on the nature and character of the political class in the country. Politics is about the distribution of power among the leading representatives of differing groups in society, but it must primarily be about solving the problems of underdevelopment. When Nigerians like their peers around Africa talk about development, what they seek is not abstract. They want a higher living standard, preferring economic changes to political ones. Political parties and the party system form a critical component in determining how much of development aspirations and goals competitive politics has helped in realizing in the country's newly established democracy.

Ironically, poverty has been on the rise, with 86.9 million Nigerians or about $50 \%$ of the country's estimated 180 million people being in extreme poverty as at 2017 , and having the highest rate of extreme poverty globally by June 2018 (Amao 2019). Corruption and its debilitating effects are becoming monstrous, with government's attempts to control being largely ineffective, while the society does not appear ready to join the fight in reducing the menace (see Falola 2018: 283-305). Elections have been generally choiceless because the poverty-stricken ordinary Nigerians, who form the bulk of the electorate, are "voting but not choosing", borrowing from the description by Marcuse (1964:7). The voters hardly can make informed choices because of a political culture largely affected by the rising levels of poverty on one hand and, on the other, by the increasing money culture in which everything including votes are openly commoditized.

The emerging and established patterns in the country's 20 years of democratization indicate conspiratorial tendencies on the part of the political class and parties with an attitude which, at best, involves mere sloganeering and little or no purposive actions. The rentier character of the state, typical of many parts of Africa, makes it the site for the use of political power for primitive accumulation, "capture" and for amassing economic power by the privileged class (see Ake 2001; Gyimah-Boadi 2007; Adejumobi 2010). Ethno-religious factors are deployed to sustain a system of social closure in which majority of the ordinary citizens, including the poor and the youths, are excluded from the network of connections, while a rigid compartmentalization between males and females is manipulated to exclude many from among the latter from effective political participation.

\section{Conclusion}

This paper has undertaken a retrospective appraisal of party politics in Nigeria since its return to democracy in 1999. To achieve this, the paper drew references from issues related to party administration and politics in Nigeria to examine the essential issues that have dominated its political space, in particular, since its return to democratic rule in 1999. The paper finds that politics and the party system in Nigeria's Fourth Republic have so far not contributed significantly to sustainable development in the country. Findings from the paper equally suggest that democracy in Nigeria is yet to be inclusive because majority of the ordinary citizens are involved mostly only when they vote. Votes are counted but so far, they seem not to count much because the living conditions of the generality of the people have not improved remarkably. 
The political parties are affected by the environment within which they operate while they also determine the well-being of their environment and society at large. Like every organization, political parties in Nigeria maintain an exchange of both input and output with their environment, prominent among which are societal values. While the state and its offices are, in many instances, abused by the representatives of the people, society is yet to rise up to its responsibility of effective engagement in public affairs and with "elected" representatives. Except with profound change in values and orientation, it is hardly practicable that political parties in today's Nigeria will do what is done elsewhere in terms of actualizing development aspirations and goals for the benefit of the greatest number of citizens. Therefore, civil society, preferably from the community levels, has critical role to play in the interest of the generality of Nigerians in the ongoing milieu of party politics of the Fourth Republic.

\section{Online Materials}

[1] www.allafrica.com -Nigeria: Obasanjo explodes; April polls do-or-die affair for PDP (accessed on 02 September 2019).

[2] www.pmnewsnigeria.com - INEC issues Okorocha certificate of return as senator - elect (accessed on 14 July 2019).

[3] www.premiumtimesng.com -Diezani Bribe: INEC Deputy Director jailed six years (accessed on 23 August 2019).

[4] www.punchng.com - Supreme Court nullifies APC candidates' elections, declares PDP. (accessed on 06 July 2019).

[5] www.qz.com -Nigeria has the highest rate of extreme poverty globally (accessed on 09 September 2019).

[6] www.saharareporters.com - Court restrains INEC from issuing certificate of return to Okorocha (accessed on 14 July 2019).

\section{References}

[1] Abubakar, A. 2013. "Thoughts on Internal Democracy in Nigerian Political Parties: Challenges and Strategies". Distinguished Personality Lecture Series, Department of Political Science, University of Ibadan, Nigeria, 13 March.

[2] Adamolekun, L (Ed.) 2002. Public Administration in Africa, Ibadan: Spectrum Books.

[3] Adebayo, A. 1981. Principles and Practice of Public Administration in Nigeria, London: John Wiley.

[4] Adejumobi, S. 2010. "INEC and the Electoral Process," in S. Adejumobi (Ed.) Governance and Politics in Post-Military Nigeria, New York: Palgrave Macmillan.

[5] Adetula, VAO. 2008. "Money and Politics in Nigeria: An Overview", V.A.O. Adetula (Ed.) Money and Politics in Nigeria, Abuja: IFES - Nigeria.

[6] Adetula, VAO. 2014. "PDP Crisis and President Jonathan's Party Management", in J.A.A. Ayoade, A.A. Akinsanya and O.J.B. Ojo (Eds.) The Jonathan Presidency: The Sophomore Year, Ibadan: John Archers.

[7] Agbaje, A. 1999. "Political Parties and Pressure Groups", in R. Anifowose and F. Enemuo (Eds.) Elements of Politics, Lagos: Sam Aroanusi.

[8] Agboke, M. 2019. "Goodwill Address", by Oyo State Resident Electoral Commissioners (REC), representative of INEC Chairman at the International Conference on 2019 Elections, organized by Programme on Ethnic and Federal Studies (PEFS), University of Ibadan, Nigeria, 25-26 June. 
[9] Akande, SO and Simbine, AT (Eds.). 2008. Electoral Reforms in Nigeria, Ibadan: NISER.

[10] Ake, C. 2001. Democracy and Development in Africa, Ibadan: Spectrum Books.

[11] Amao, O.B. 2016. "Revisiting Nigeria's 29 Years of Military Adventurism: A Blessing or Curse?" in D.A.,Yagboyaju, (Ed.) Reflections on Politics, Governance, and Economy in Contemporary Nigeria, University of Ibadan Press, Ibadan, Nigeria.

[12] Amao, O.B. 2020. “A Decade of Terror: Revisiting Nigeria's Interminable Boko Haram Insurgency”. Security Journal, pp.1-19.

[13] Amao, O.B. 2020. Nigeria's 2019 General Election: What does it mean for the rest of the world? The Round Table: Commonwealth Journal of International Affairs, 109 (4), pp.429-440.

[14] Anifowose, R. 1982. Violence and Politics in Nigeria: The Tiv and Yoruba Experience, Enugu: NOK Publishers.

[15] Beard, CA. 1939. "Philosophy, Science and Art of Public Administration". Address at the Annual Conference of the Governmental Research Association, Princeton, New Jersey, 08 September.

[16] Berlin, I. 2013. The Pursuit of the Ideal", in I. Berlin (Ed.) The Crooked Timber of Humanity: Chapters in the History of Ideas, Princeton, New Jersey: Princeton University Press.

[17] CDD. 2019. Updates on Elections of March 9, 2019, Abuja: CDD.

[18] Coleman, JS. 1971. Nigeria: Background to Nationalism, Berkeley: University of California Press.

[19] Diamond, L. 1988. Class, Ethnicity and Democracy in Nigeria: The Failure of the First Republic, London: The Macmillan Press.

[20] Dimock, ME. 1937. The Study of Administration, American Political Science Review, Vol. 31, No. 1, p. 29.

[21] Dudley, BJ. 1968. Parties and Politics in Northern Nigeria, London: Frank Cass.

[22] Duverger, M. 1978. Political Parties, Their Organization and Activity in the Modern State, London: Methuen.

[23] Egwu, S; Leonard, DK and Matlosa, K. 2009. Nigerian Elections since 1999: What does democracy mean? Journal of African Elections, Vol. 8, No. 1, pp. 108-144.

[24] Electoral Reform Committee. 2008. Report of the Electoral Reform Committee, Vol. 1, Main Report, Abuja.

[25] Eme, OI and Anyadike, N. 2014. Political Financing in Africa - A Comparative Study of Kenya and Nigeria: Proposal for Reform, Mediterranean Journal of Social Sciences, Vol. 5, No. 27, pp. 22-34.

[26] Falola, T. 2018. "Political Economy and the Culture of Underdevelopment", in T. Falola (Ed.) The Toyin Falola Reader on African Culture, Nationalism, Development and Epistemologies, Austin, Texas: Pan-African University Press.

[27] Federal Republic of Nigeria (FRN). 2002. The Electoral Act, Abuja: Federal Ministry of Information (FMOI).

[28] First, R. 1970. The Barrel of a Gun: Political Power in Africa and the Coup d'etat in Africa, London: Penguin.

[29] FRN. 2010. The Electoral Act, Abuja: FMOI.

[30] Gau, J. 1947. The Ecology of Government: Reflections on Public Administration, Alabama: University of Alabama Press. 
[31] Gyinah-Boadi, E. 2007. "Political Parties, Elections and Patronage: Random Thoughts on NeoPatrimonialism and African Democratization", in M. Basedau, G. Erdmann and A. Mehler (Eds.) Votes, Money and Violence: Political Parties and Elections in Sub-Saharan Africa, Uppsala: Nordic Africa Institute.

[32] Gulick, LH. 1937. "Notes on the Theory of Organization", in L.H. Gulick (Ed.) Papers on the Science of Administration, London: Institute of Administration.

[33] Hodgkin, T. 1961. African Political Parties: An Introductory Guide, London: Penguin.

[34] Ihonvbere, J. 2009. "Leadership and the Future of Nigeria". Foundation Day/Distinguished Public Lecture, Lead City University, Ibadan, Nigeria, 12 March.

[35] Independent National Electoral Commission (INEC). 2017. Political Finance Manual 2017, Abuja: INEC.

[36] Iwu, M. 2008. “The April 2007 Elections in Nigeria: What went Right?” Distinguished Personality Lecture, Department of Political Science, University of Ibadan (UI), Nigeria, 15 April.

[37] Jinadu, LA. 2019. "Elections, Democracy and the State in Africa: The 2019 Nigeria Elections in Perspective". Keynote Address at the International Conference on 2019 Elections in Nigeria, organized by Programme on Ethnic and Federal Studies (PEFS), UI, Nigeria, 25-26 June.

[38] Joseph, R. 1987.Democracy and Prebendal Politics in Nigeria: The Rise and Fall of the Second Republic, Oxford: Cambridge University Press.

[39] Kapur, D and Vaishnav, M (Eds.). 2018. Costs of Democracy: Political Finance in India, Delhi: Oxford University Press.

[40] Kehinde, A. 2016. "Self Interest, Public Interest and Governance in Africa: The Perspective of Post-Colonial African Literature; in O.A. Oyeshile and F. Offor (Eds.) Ethics, Governance and Social Order in Africa, Ibadan: Zenith Book House Ltd.

[41] Kirk-Greene, A and Rimmer, D. 1981. Nigeria since 1970: A Political and Economic Outline, London: Hodder and Stoughton.

[42] Kumuyi, J and Adeyinka, F. 2002. "Technology as a Tool”, in D. OluAjakaiyeand F.O. NyemutuRoberts(Eds.) Meeting the Challenges of Sustainable Democracy in Nigeria, Ibadan: NISER.

[43] Lalude, G. 2014. "Nigerian Governors Forum Crisis", in J.A.A. Ayoade, A.A. Akinsanya and O.J.B. Ojo (Eds.) The Jonathan Presidency: The Sophomore Year, Ibadan: John Archers.

[44] La Palombara, J and Weiner, M. 1966. "The Origin and Development of Political Parties", in J. La Palombara and M. Weiner (Eds.) Political Parties and Development, Princeton: Princeton University Press.

[45] Leeds, CA. 1981. Political Studies, Estover, Plymouth: Macdonald \& Evans.

[46] Londono, JF and Zovatto, G. 2014. "Latin America", in E.J.S. Falguera and M. Ohman (Eds.) Funding of Political Parties and Election Campaign: A Handbook of Political Finance, Stockholm, Sweden: IDEA.

[47] Marcuse, H. 1964. One-Dimensional Man, Boston: Beacon.

[48] Mclean, I and Mcmillan, A (Eds.). 2009. Oxford Concise Dictionary of Politics, New York: Oxford University Press.

[49] Michels, R. 1911. Political Parties, London: Methuen.

[50] NBS. 2015. National Bureau of Statistics Annual Report, Abuja: NBS.

[51] NSE. 2015. Nigerian Stock Exchange Market Report, Abuja: NSE. 
[52] Okoosi-Simbine, AT. 2004. "The Impact of more Parties on the Democratic Project:, in H.A. Saliu (Ed.) Nigeria Under Democratic Rule, 1999-2003, Ibadan: Ibadan University Press.

[53] Okoosi-Simbine, AT. 2005. "Political Vagrancy and Democratic Consolidation in Nigeria", in G. Onu and A. Momoh (Eds.) Elections and Democratic Consolidation in Nigeria, Lagos: ATrial Associates.

[54] Okoosi-Simbine, AT. 2007. "Women Marginalization and Politics in Nigeria: A Review Essay", in I.O. Albert, D. Marco and V. Adetula(Eds.) Perspectives on the 2003 Elections in Nigeria, Abuja and Ibadan: IDASA and Stirling-HordenPublishers Ltd.

[55] Olaopa, T. 2019. “Can a weak leader build strong institutions?” The Punch (Lagos, Nigeria), 21 May, p. 16.

[56] Olaniyan, A., and Amao, O.B. 2015. "Election as Warfare: Militarization of Elections and the Challenges of Democratic Consolidation in Nigeria". International Affairs Forum, 6(1), pp.7081.

[57] Olatunbosun, A. 2018. "Nigeria's Multi-Party System as Platform for Forum Shopping”. Public Lecture in commemoration of the $40^{\text {th }}$ Remembrance Anniversary of Chief MojeedAgbaje, Ibadan, 19 November.

[58] Olorunmola, A. 2017. Cost of Politics in Nigeria, London, UK: Westminster Foundation for Democracy.

[59] Olurode, L. 2012. Nigeria: The Money Culture and Election Campaign Finance, IFES Nigeria Political Finance Newsletter, Vol. 3, No. 9, p. 4.

[60] Olurode, L. 2017. “The Slaughter's Slab as a Metaphor” Inaugural Lecture, University of Lagos, Nigeria, 22 March.

[61] Olurode, L. 2017a. Technology and Election Conundrum: A Case of Nigeria, Sociology and Anthropology, Vol. 5, No. 10, pp. 799-811.

[62] Olurode, L. and Jega, A (Eds.) 2011. Security Challenges of Election Management in Nigeria, Lagos: Friedrich Ebert Stiftung and INEC.

[63] Omilusi, M. and Amao, O, B. 2019. "Between Military Resistance and Democratic Consolidation Epochs: Is Nigeria's Civil Society Still Vibrant or Docile?” Journal of Science, Humanities and Arts, 6(6), p.1-28.

[64] Oni, B and Simbine, AT. 2002. "Intergenerational Challenges", in D. OluAjakaiye and F.O. Nyemutu Roberts (Eds.) Meeting the Challenges of Sustainable Democracy in Nigeria, Ibadan: NISER.

[65] Onuoha, B. 2002. "Transition, Democracy and the Debate on the Funding of Political Parties in Nigeria", in B. Onuoha and M.M. Fadakinte (Eds.) Transition Politics in Nigeria, 1970-1999, Lagos: MaltHouse Press Ltd.

[66] Organization of American States (OAS). 2011. Politics, Money and Power: A Dilemma for Democracy, Mexico: OAS.

[67] Oshun, O. 2005. The Kiss of Death: Afenifere and the Infidels, United Kingdom: Josel Publishers.

[68] Post, KWJ. 1963. The Nigerian Federal Elections of 1959, Oxford: Oxford University Press.

[69] Riggs, FW. 1962. Trends in the Comparative Study of Public Administration, International Review of Administrative Sciences, Vol. 28, No. 1, pp. 9-15.

[70] Roberts, FON. 2010. "Issues in the Evolution of Nigerian Elections", in S.O. Akande and A.J. Kumuyi (Eds.) Nigeria at 50-Accomplishments, Challenges and Prospects, Ibadan: NISER. 
[71] Simbine, AT and Oladeji, A. 2010. "Overview Challenges and Prospects of Governance and Political Development", in S.O. Akande and A.J. Kumuyi (Eds.) Nigeria at 50Accomplishment. Ibadan: NISER.

[72] Sklar, RL. 1966. “The Ordeal of Awolowo”, in G. Carter (Ed.) Politics in Africa: 7 Cases, New York: Harcourt Brace \&World

[73] Sklar, RL. 1983. Nigerian Political Parties: Power in an Emergent African Nation, London: NOK Publishers.

[74] Sule, B; Azizuddin, MS and Mat, B. 2017. Independent National Electoral Commission and Campaign Financing Monitoring in Nigeria: The 2015 General Elections, Journal of International Studies, Vol. 13, No. 1, pp. 15-31.

[75] Ugochukwu, B. 2009. Democracy by Court Order, Lagos: Legal Defence Centre.

[76] UNECA. 2013. African Governance Report III: Elections and the Management of Diversity, Oxford: Oxford University Press.

[77] USAID/UKAID. 2015. Still Above the Ceiling, Washington, DC: Center for Social Justice.

[78] Uscinski, JE; Klofstad, C and Atkinson, MD. 2016. What drives Conspiratorial Beliefs? The Role of Informational Cues and Predispositions, Political Research Quarterly, Vol. 69, No. 1, pp. 57-71.

[79] Walecki, M. 2008. "Political Money and Corruption: Limiting Corruption in Political Finance", in V.A.O. Adetula (Ed.) Money and Politics in Nigeria, Abuja: IFES.

[80] Yagboyaju, DA. 2007. Nigeria and the Challenge of Democratic Consolidation: The Fourth Republic Experience, African Journal of International Affairs and Development, Vol. 12, Nos. $1 \& 2$, pp. 34-57.

[81] Yagboyaju, DA. 2009. "Election Finance and Nigeria's Democratization: Lessons from the 2007 General Elections", in L. Olurode, S. Akinboye and R. Akinyemi (Eds.) Nigeria's 2007 Elections: The Crisis of Political Succession, Lagos: Rebonik Publications Ltd.

[82] Yagboyaju, DA. 2016. "The Concepts of Governance and Administration”, in D.A. Yagboyaju (Ed.) Reflections on Politics, Governance and Economy in Contemporary Nigeria, Ibadan: Ibadan University Press.

[83] Yagboyaju, DA. 2019. "Political Defections and Democracy in Nigeria", in O. Fagbohun and A. Aderemi(Eds.) Statesmanship and Political Leadership: Analyses of Nigeria's Fourth Republic, Lagos: LASU.

[84] Yagboyaju, DA. 2019a. Culture Impact on Public Administration and Governance in Africa: The Nigerian Case, African Journal of Public Administration and Management, Vol. xxvi, No. 1 (January-June), pp. 109-123.

[85] Yaqub, N. 1992. The Third Republic, the Military and the Institutionalization of Democracy in Nigeria, Studies in Politics and Society, Issue 7 (August), pp. 41-66.

[86] Yaqub, N. 2002. "Political Parties in the Transition Process", in B. Onuoha and M.M. Fadakinte (Eds.) Transition Politics in Nigeria, 1970-1999, Lagos: MaltHouse Press Ltd.

[87] YIAGA Africa. 2019. Watching the Vote: 2019 Governorshipand State Assembly SupplementaryElection, Preliminary Statement on Accreditation, Voting and Results Collation, 24 March, p. 4. 